This item was submitted to Loughborough's Research Repository by the author.

Items in Figshare are protected by copyright, with all rights reserved, unless otherwise indicated.

\title{
Disruptive innovation ... in reverse: Adding a geographical dimension to disruptive innovation theory
}

PLEASE CITE THE PUBLISHED VERSION

https://doi.org/10.1111/caim.12043

PUBLISHER

Wiley

VERSION

AM (Accepted Manuscript)

\section{PUBLISHER STATEMENT}

This is the peer reviewed version of the following article: CORSI, S. and DI MININ, A. , 2014. Disruptive innovation ... in reverse: Adding a geographical dimension to disruptive innovation theory. Creativity and Innovation Management, 23(1), pp. 76 - 90, which has been published in final form at https://doi.org/10.1111/caim.12043. This article may be used for non-commercial purposes in accordance with Wiley Terms and Conditions for Use of Self-Archived Versions.

\section{LICENCE}

CC BY-NC-ND 4.0

\section{REPOSITORY RECORD}

Corsi, Simone, and Alberto Di Minin. 2019. "Disruptive Innovation ... in Reverse: Adding a Geographical Dimension to Disruptive Innovation Theory”. figshare. https://hdl.handle.net/2134/9849821.v1. 


\section{creativity and}

innovation management

\section{Disruptive Innovation...in Reverse: a Theoretical Framework to Look at New Product Development from Emerging Economies}

\begin{tabular}{|r|l|}
\hline Journal: & Creativity and Innovation Management \\
\hline Manuscript ID: & 0646-CIM-A-10-2012 \\
\hline Manuscript Type: & Article \\
\hline Keywords: & $\begin{array}{l}\text { disruptive innovation, reverse innovation, emerging economies, product } \\
\text { development, cost innovation, R\&D internationalization }\end{array}$ \\
\hline
\end{tabular}

SCHOLARONE ${ }^{m}$

Manuscripts 
Disruptive Innovation...in Reverse:

A Theoretical Framework to Look at New Product Development from Emerging Economies

Word count: 6175

29

30

32

33

34

35

36

37

38

39

40

42

43

44

45

46

47

48

49

50

51

54

55

56

57

58

59

60 


\section{Introduction}

What role do emerging economies play in the global innovation system? This paper attempts a reinterpretation of the concept of Reverse Innovation (Immelt et al, 2009; Govindarajan and Trimble, 2012), defined as a type of disruptive innovation (Christensen, 1997).

In our literature review, we argue that the combination of these two theories provides a useful framework to look at emerging economies as sources of new products and technological solutions.

Several authors are investigating - on a limited empirical basis for the time being - in what way these countries are not only recipients (Vernon, 1966) but also sources of innovation (Hart and Christensen, 2002; Immelt et al, 2009; Govindarajan and Trimble, 2012; Kenney et al, 2009).

Although several authors have identified and discussed the process of innovation from emerging economies, it remains under-explored. They refer to this trend in different ways, depending on the aspect they focus on, such as disruptive innovation from emerging economies, innovation at the bottom of the pyramid, cost-innovation, reverse innovation. However managerial literature is still lacking both a clear and solid theoretical position and a strong theoretical framework within which a new innovation trend from emerging economies can be read and interpreted. .

Hence, the aim of this paper is to critically review the literature concerning innovation from emerging economies and contributing a rationalization of the related concepts. We then view the disruptive innovation and reverse innovation paradigms side by side: two theories that we think offer interesting and complementary perspectives when we position emerging markets at the centre of the stage as a source of innovation.

In the last ten years, scholars have started to look at companies that serve those markets in a different way. Glocalization - adapting to emerging markets products developed for advanced ones - is in fact assumed to be partially "blind" or ineffective for the purpose of serving emerging market needs given its ability to reach only the wealthier part of the population. The new challenge of the $21^{\text {st }}$ century has been identified in the profitable development and sale of new products for the mass markets of less affluent populations of emerging economies that are currently not, or only partially, served by MNCs. Innovation management literature has produced a limited number of studies (Hart \& Christensen, 2002; Prahalad, 2004; Immelt et al, 2009; Hang et al, 2010; Govindarajan and Trimble, 2012), largely based on anecdotal evidence, trying to identify new ways of pursuing innovation in emerging economies. Most of these studies build, more or less implicitly, their argument on the well-known disruptive innovation paradigm as defined by Christensen (1997) and Christensen \& Raynor (2003), further derived as disruptive innovation in emerging economies in Prahalad's seminal work on innovation for the bottom of the pyramid (BOP) (Prahalad, 2004).

Given the specificity of the context for and in which these innovations need to be developed domestic companies seem to be best placed to pursue them. By virtue of their embeddedness, local market knowledge and low cost approach, they develop new product solutions for emerging markets that challenge the activities of foreign MNCs. This phenomenon has mostly been referred to as cost innovation (Zeng \& Williamson, 2007). Indeed, growing attention has been paid to companies from emerging economies and how in going global they threaten western MNCs in the home markets that they have dominated for decades. Responding to this threat is a new challenge for incumbent MNCs and, in our opinion, disruptive innovation is in some way useful to describe the new trend that has recently been defined as reverse innovation (Immelt et al, 2009). According to Immelt et al (2009) and Govindarajan and Trimble (2012), since most current and future global 
economic growth is likely to take place in emerging economies, innovation specifically aimed at responding to these markets is crucial. In order to do this, subsidiaries in emerging economies have to be granted full decision-making authority in the markets they serve. The success of such a strategy would not only be in anticipating or challenging "emerging" MNCs, but also in granting new growth opportunities to "developed" MNCs in their home markets with technologies and products that would not have been developed without emerging market inputs (Kenney et al, 2009). Indeed, new products developed entirely in emerging markets for emerging markets are likely to disrupt developed markets and open new business opportunities. This phenomenon thus configures a process of innovation that no longer sees developed economies as the locus where new products are conceived, designed and commercialized but instead take on the role of the last recipient of innovations developed in and for emerging economies.

This paper builds on the disruptive innovation literature and contrasts its analysis with the concept of reverse innovation. We believe we bring two theoretical contributions:

1. We support the idea that disruptive innovation - as defined by Christensen (1997) and intended for advanced economies - needs to be adapted and reinterpreted to be useful in analyzing new business that originates from emerging economies.

2. We suggest that reverse innovation - as defined by Immelt et al (2009) and Govindarajan and Trimble (2012), and intended to explain a phenomenon originating from emerging countries - fits the definition and is hence a particular manifestation of disruptive innovation.

The paper is organized as follows. In the next section, we lay the foundations of our analysis by reviewing Disruptive Innovation Theory. This will be used as our framework to interpret the other sections that take into account disruptive innovation as considered in the different streams of literature related to innovation in emerging economies. Section 3 explores the dynamics of innovation at the Bottom of the Pyramid (BOP) while section 4 investigates the conceptualization of disruptive innovation from emerging economies,. The concept of reverse innovation is introduced in section 5 and interpreted within the Disruptive Innovation framework in section 6. Section 7 provides a new categorization of Disruptive Innovation considering a geographical dimension. Finally, conclusions and future research directions are provided in section 9.

\section{Disruptive Innovation}

Introduced in 1995 by Bower and Christensen, the concept of disruptive innovation was refined by Christensen in 1997 with his "Innovator's Dilemma", asking why great companies pursuing innovation in mainstream markets suffer from market myopia and are overtaken by entrant firms introducing products based on new-disruptive technologies.

To explain these phenomena, the author distinguishes between sustaining and disruptive technologies. The former are technologies that respond to an improvement, radical or incremental, of "established products, along the dimensions of performance that mainstream customers in major markets have historically valued" (Christensen, 1997, p. XV). Disruptive technologies instead are innovations for existing products but on attributes that differ from those that are mainly valued by mainstream customers. These innovations, which initially underperform with respect to the main attributes of sustaining technologies, become disruptive when they reach the same performance as 
the sustaining innovations on the attributes valued by mainstream customers. At this point, they displace existing technologies and cause, in most cases, the failure of incumbent firms.

In earlier works, Christensen (Bower \& Christensen, 1995; Christensen, 1997) refers to disruptive technology only as an "innovation that results in worse product performance in mainstream markets". It is also described as a "typically cheaper, simpler, smaller and frequently more convenient to use" version of an existing product.

In an updated version of the concept, Christensen and Raynor (2003) distinguish between lowend disruptions and (new-market) high-end disruptions. The former are those offering lower performance at a cheaper price but no other performance improvements, while the latter are described as products and services that offer better performance on attributes that differ from those valued by mainstream customers.

Christensen also asserts that disruptive technologies should be framed as a marketing, and not a technological, challenge. Firms succeeding in disruptive innovations have a strong attitude in interpreting and addressing needs expressed by a market niche or a new market segment. Thus, the challenge that incumbent firms should overcome in developing and responding to disruptive innovations relates to the development of capabilities to forecast market trends and attitudes as well as "riding" new technological trajectories (Suzuki \& Kodama, 2004; Corso \& Pellegrini, 2007).

Disruptive innovation has been used from the very beginning to discuss innovation dynamics taking place with the entry of new companies in established and developed markets (Chesbrough, 2002). One of the most convincing responses provided by researchers, albeit widely discussed and doubted (Danneels, 2004), is that these companies should promote the creation of spin-off enterprises in order to better serve and interpret emerging markets. The creation of a separate organization of a smaller dimension with large autonomy allows overcoming the problem of resource allocation that is too mainstream-customer oriented. Matching the initially small market size to the size of the investment potentially enables the new company to be profitable (Cefis \& Marsili, 2006; Sandström et al, 2009).

Since its coinage, the concept of disruptive innovation has been widely discussed from different perspectives (Danneels, 2004; Henderson, 2006).

In particular, Govindarajan and Kopalle (2006a; 2006b) make a clear distinction between lowend and high-end disruptions based on the level of radicalness of disruptive innovations (technologically more radical in high-end disruptions, technologically less radical in low-end disruptions). The authors also make a clear distinction between innovations that are radical and disruptive and merely radical, stating that radicalness is a technology-based concept while disruptiveness is a market-based concept. Analogously, Markides (2006) draws a clear distinction between different kinds of disruptive innovations: technological, business model and new-to-theworld product innovations. From this distinction and from the work of Utterback (2004), Acee's (2001), and Utterback \& Acee (2005), who recognized the importance of disruptive technologies not in the fact that they displace existing products but in their ability to enlarge existing markets and provide new functionalities, Govindarajan \& Kopalle add rigor to an expanded view of disruptive innovation including both high-end and low-end disruptions and defining the concept as follow (2006a, p.190):

"A disruptive innovation introduces a different set of features, performance and price attributes relative to the existing product, an unattractive combination for mainstream customers at the time 
of product introduction because of inferior performance on the attributes these customers value and/or a high price - although a different customer segment may value the new attributes. Subsequent developments over time, however, raise the new product's attributes to a level sufficient to satisfy mainstream customers, thus attracting more of the mainstream market".

In the examples of disruptive technologies provided by Christensen (1997) and Christensen \& Raynor (2003), the new market segment that adopt the disruptive solution belongs to the same market where incumbent companies operate. The emergence of new technologies triggers interest within the mainstream segment where these incumbents operate, hence rendering access to the disruptive offering (initially not desired) also possible to mainstream customers.

In conclusion, we can argue that disruptive innovation is a theory that seeks to explain changes and new entries in established markets. The result of disruptive innovation is visible when mainstream customers switch to the new disruptive product that is gaining market share on established markets.

What if the new disruptive solution has been brought to maturity and has triggered interest in markets that are geographically distant and disconnected from established markets? Disruptive innovation theory was not developed, and is as yet too unrefined, to explain this phenomenon.

\section{Innovation at the Bottom of the Pyramid (BOP)}

While the disruptive innovation paradigm explores the dynamics originating within the hub of an industry, a new approach was developed to understand what was taking place in emerging economies and their markets. This orientation brought scholars to thinking of emerging economies as focal markets to which companies should pay increasing attention and develop a new R\&D orientation (Prahalad \& Hart, 2002).

Traditionally, MNCs delocalized their R\&D oriented FDI in emerging economies for two main reasons (Gassman \& Han, 2004; Von Zedtwitz, 2004):

- Access to local markets

- Access to high-skilled research personnel at a lower cost

Following these two drivers, most R\&D carried out by foreign MNCs in emerging countries consisted in the adaptation of global products to the specific needs of the local market. R\&D, crucial for the development of new products, has traditionally been undisclosed by headquarters (Patel \& Pavitt, 1991; Di Minin \& Bianchi, 2011), and this is particularly true of R\&D internationalization in emerging economies.

The new perspective in the early 2000s was that emerging market potential was not exploited with the previous approach and that a new type of innovation management had to be developed.

Companies noted that responding to local market needs with a simple local adaptation of global products developed in their (mainly) western headquarters (glocalization) was ineffective in exploiting the entire potential of these growing markets (London \& Hart, 2004).

Prahalad and Hart (2002), and later on Prahalad (2004), introduced the new approach to emerging economies as a source of significant profit generation through the development and commercialization of ad-hoc products and services for the markets of the poor. 
Prahalad's approach is expressed in the title of his famous 2004 book "The Fortune at the Bottom of the Pyramid: Eradicating Poverty through Profits". The author identifies a large opportunity for MNCs operating in emerging economies.

According to Prahalad's perspective, MNCs serving only the top of the pyramid (the wealthier parte of the population) in emerging economies suffer from business myopia in a way that closely recalls the marketing challenge that Christensen's incumbent firms faced in developing disruptive innovation for new or emerging market niches.

What is of great interest to us is that, although there is no direct and explicit link between these theories, the BOP concept shares some similarities with the disruptive innovation paradigm (Hart \& Christensen, 2002). It suggests developing products and services for a market segment requesting different attributes than those of mainstream customers and, in particular, access to the same technology at a much lower price. In reality, it addresses a market that does not yet exist, seemingly configuring what Govindarajan and Kopalle (2006a, 2006b) identify as disruptive innovation that creates a new market. In our opinion, innovation at the BOP cannot be easily, or entirely, assimilated with disruptive innovation theory. We will explain why in the next section, explicitly linking the BOP to the disruptive innovation paradigm.

\section{Disruptive Innovations from Emerging Economies}

Parallel to the work on "Serving the Bottom of the Pyramid", a further wave of exploration was initiated by scholars linking the disruptive innovation paradigm and Prahalad's non-served markets of the poorest in emerging economies (Hart \& Christensen, 2002; London \& Hart, 2004).

The argument of scholars applying disruptive innovation to explain the success of new products originating from emerging economies is as follows: foreign MNCs develop products for emerging markets and later use them to penetrate the low-end segment of developed markets in the US and Europe, and domestic firms leverage on their cost structure and knowledge of the domestic context to serve local, and later developed, markets.

To the best of our knowledge, Hart and Christensen (2002) for the first time introduced the link between the disruptive innovation framework and emerging economies. Their argument is clearly in line with Prahalad's work referring to "innovation from the base of the pyramid". The authors propose examples of Asian companies that succeeded in introducing disruptive innovations in lowincome countries, enabling poor people to afford certain types of technological products and generating profits for themselves.

Recently, Hang et al (2010), demonstrated four cases of Asian companies that, starting from their low-income markets (China and India), developed disruptive products. The success pursued in these markets brought them performance improvements on attributes that had at first been neglected and valued by mainstream customers in developed economies. This pushed them to invest globally and to steadily grow in developed economies.

We believe that in both works cited above, the disruptive innovation concept is used in a way that differs from the traditional application of the concept within established markets in developed economies. The traditionally defined disruptive innovation paradigm (Bower \& Christensen, 1995; Christensen, 1997) claims that new products (or services) are considered disruptive when they respond to an ignored and new market segment that is usually small, unprofitable for incumbents and has differentiated needs in terms of product attributes. 
Could we say that the idea of innovation originating in emerging markets presented by Hart \& Christensen (2002) is indeed a disruptive innovations?

We think this is true only in part, and that three limitations need to be considered in relation to the characteristics of disruptiveness mentioned above. In particular, we need to consider 1) the categorization of mainstream and non-mainstream customers 2) market size and 3) disruptive innovators (see Table 1):

1. Foreign MNCs operating in emerging economies have traditionally served those markets adopting a glocalization approach to market segmentation, thus serving customers that correspond and share similar characteristics to those segments served back in their country of origin or in developed markets. These are their mainstream customers, who might represent the great majority at home but in emerging economies represent only the top of the pyramid. Adopting a marketing perspective instead, as the disruptive challenge requires us to (Christensen, 1997; Danneels, 2004), mainstream customers in emerging markets should be defined as the large part of the population (be it individuals or companies) that cannot afford expensive state of the art technology and that are partly served by local companies that can interpret their needs and respond to them thanks to their cost-structure.

2. One of the main challenges that incumbent firms face when developing or responding to disruptive innovations in their markets is that the size of the emerging market with different requirements is too small to cover the development costs of new products (Christensen, 1997; Christensen \& Raynor, 2003). Indeed, the size of the market does not match the size of the company and its related cost structure as it does in the case of small entrants or spin-off companies. This is not true in emerging economies where the market served by innovations, as in the cases presented in Hart \& Christensen (2002) and Hang et al (2010), is much bigger than that served by glocal products so that the market size is potentially huge, assuming that access to these market segments is feasible.

3. Disruptive innovations in developed economies generally come from a small entrant firm (e.g., a start-up company) that is generated by either a new entrepreneurial activity or a spin-off company from an incumbent firm (Bower \& Christensen, 1995; Christensen, 1997; Christensen \& Raynor, 2003; Walsh et al, 2002). The generation of disruptive innovations in emerging economies could be developed by domestic companies that naturally have a cost structure and a market orientation that fits the local environment and by subsidiaries of MNCs that have evolved and gained enough autonomy to develop new products. The case of companies from emerging markets is well described by Zeng and Williamson (2007) who report on how innovations developed by Chinese companies are disrupting global markets by primarily leveraging on new, low-cost based, business models. The innovative approach of these companies is defined by the authors as cost innovation.

\section{Reverse Innovation}

In the previous sections, we showed how the disruptive innovation paradigm does not adequately fit the description of innovations developed for emerging economies and afterwards "exported" back to developed economies. Reverse Innovation (Immelt et al, 2009; Govindarajan and Trimble, 2012) is a more suitable concept that helps us understand this trend. This new line of research argues that innovation is less likely to come from, and is adopted in, developed countries first, but is 
conceived and adopted in emerging economies first to then be introduced to developed markets. It is then "exported" to the developed economies. These dynamics reverse the innovation process as intended in past literature and managerial practice. The reasons that support such an inverted process lie in the market growth of the developing countries that are supporting and leading the global economy.

In their article "How GE is disrupting itself" (2009), Immelt et al show how GE is benefiting from its presence in the markets of emerging economies, specifically China and India, to develop breakthrough innovations that are introduced and successfully commercialized first in developing countries and later, when performance improvements are acceptable, in developed countries. They provide clear examples for GE Healthcare developing and perfecting products in both China (Immelt et al, 2009) and India (Govindarajan and Trimble, 2012) before selling them in those markets first and in advanced ones later on, disrupting existing products in some markets as a result of performance improvements on the attributes most valued by mainstream customers.

The authors stress the importance of Local Growth Teams (LGTs) as new units, independent from their MNC HQ, built from scratch in emerging economies. They are responsible for the complete development and commercialization of products leveraging HQ technology but developing completely new offerings that match the market they operate in.

They explain how in order to compete in emerging economies, foreign MNCs have to rely on LGTs in order to develop innovations that fit local needs and overcome local constraints. At the same time, they do not neglect the glocalization paradigm in line with which MNCs have to continue to operate to serve high-end markets and build part of the technological knowledge that is essential for the activities of LGTs in emerging economies.

\section{Overlapping Areas Between Disruptive and Reverse Innovation}

Despite the above considerations, the innovation concept that the authors define as reverse innovation is, in our opinion, a form of disruptive innovation. The characteristics that Immelt et al (2009) and Govindarajan and Trimble (2012) list and illustrate to describe reverse innovation match those described in the previous sections of this paper recalling the disruptive innovation theory as illustrated by Christensen \& Bower (1995), Christensen (1997), Christensen \& Raynor (2003), Acee (2001), Utterback \& Acee (2004), Govindarajan \& Kopalle (2006a, 2006b). In particular, reverse innovation shares great similarities with the concept of disruptive innovation from emerging economies as illustrated by Hart \& Christensen (2002), Zeng and Williamson (2007) and Hang et al (2010).

Govindarajan and Trimble (2009) responded to this parallelism themselves following the requests of some readers of their paper who asked for clarification between disruptive innovation and reverse innovation. In one of Govindarajan's blog post they list a set of conditions that reverse innovation can originate from stating that the one concerning a lower price offer is the only one configuring it also as a disruptive innovation. (September 30, 2009 ${ }^{1}$ ). They thus consider disruptive innovation only from a price/performance point of view, and not as a market widener or a provider of new functionalities, implicitly stating that disruptive innovation can only have a lower price.

We do not believe this is completely true. Referring back to Govindarajan's works on disruptive innovation, we note that Govindarajan \& Kopalle (2006b) define disruptive innovation as " $a$ 
powerful means for broadening and developing new markets and providing new functionality, which, in turn, disrupt existing market linkages"

Therefore, the focus now lies in the alternative attributes that are offered by the innovation in relation to an existing product. These new products are able to penetrate the market starting from early adopters and improve performance in the "mainstream" thanks to the experience accumulated in serving the new segment. In line with Christensen \& Raynor (2003) and Utterback \& Acee (2005), Govindarajan and Kopalle (2006a) define disruptive innovation in the way presented in the second section of this paper and include both new, low-end and high-end attributes to existing products that initially are tempting only to new customers (thus not necessarily price-focused) or the most price sensitive mainstream customers, but in developing over time they also gain the attention of mainstream customers and the market.

In summary, Govindarajan and Trimble state that reverse innovation has three drivers (although Govindarajan stresses the fundamentality of the income gap) but they do not provide any example of reverse innovation that is not linked to the income gap and thus that is not in the shape of disruptive innovation. Based only on this argument, we cannot exclude a complete overlap between the two concepts. Indeed, even if we consider the other two situations (infrastructure and sustainability gap) where reverse innovation can occur, they can certainly give origin to both lowend and high-end disruptive innovations as intended by Govindarajan and Kopalle (2006a).

Beyond the conceptual similarities we have discussed up to now, reverse innovation and disruptive innovation from emerging economies (developed by foreign MNCs) have some other common points:

- the same risks of cannibalizations for companies that have previously invested in the same industries for mainstream customers (Immelt et al, 2009; Govindarajan \& Kopalle, 2006a, 2006b), which is also a tool for measuring the potentiality of firms to develop disruptive innovations (Govindarajan \& Kopalle, 2006b).

- as anticipated by Seely Brown \& Hamel (2005), Williamson \& Zeng (2004), Williamson (2005), Zeng \& Williamson (2007) and Williamson (2010) with reference to business models, disruptive innovations are a tool to pre-empt giants from emerging economies that are going global with a new price-performance offering, which is exactly the same purpose of reverse innovation (Immelt et al, 2009).

- LGTs that Immelt et al (2009) and Govindarajan and Trimble (2012) explain as crucial for the development of innovations for emerging economies mirror the spin-off companies described by Christensen \& Overdorf (2000), Christensen et al (2000), Christensen \& Raynor (2003), Danneels (2004; 2006), as the best solution for incumbents that want to compete with or develop disruptive innovations.

We therefore believe the main contribution of reverse innovation as described by Immelt et al (2009) and Govindarajan and Trimble (2012) is to be interpreted within the disruptive innovation paradigm, particularly with reference to innovations developed thanks to the market inputs of emerging countries.

We believe that Immelt et al (2009) and Govindarajan and Trimble (2012) make an important contribution, enriching the disruptive innovation paradigm from the emerging countries perspective by stressing the importance of LGTs in developing new products for local markets. 


\section{Geographic Dimension of Disruptive Innovation}

As discussed in the previous section, it is possible to see reverse innovation as a particular manifestation of disruptive innovation. Can we thus simply generalize the findings and implications of disruptive innovation originating from developed countries to situations of reverse innovation?

The answer is no. Such a generalization does not work, since success stories of disruptive innovation originating from developed markets differ substantially from success stories that export successful products back to developed markets that were first introduced in emerging economies.

Table 1 summarizes the main differences discussed below:

- Early market: in disruptive innovation theory, the market segment served by the new technology is characterized by early adopters. In reverse innovation, the early market is instead represented by the large part of the population, or BOP, that has no access to the established technology because it is either too expensive or too complex. This is hardly the case with early adopters and developed markets. These differences should lead to completely different marketing strategies.

- Actors: the small size of the early market in disruptive innovation theory makes spinoff companies or small new entrants the only actors able to serve this market profitably. On the other side, the vast size of the new market segment to be served in emerging economies allows foreign MNCs subsidiaries and large local companies to make profit from it by exploiting economies of scale.

- Expansion: the evolution of disruptive products conceived in and for developed markets brings innovative technologies to commercialization in the same markets as the established ones, while disruptive products introduced in and for developing economies allow foreign MNCs and domestic companies to export their evolved disruptions to mainstream markets in developed countries, configuring a process of reverse innovation.

- Maturation of technology: the technological evolution of disruptive innovations is the same in both cases, but while in disruptive innovation theory this occurs in the same country market, in reverse innovation we see it happening in developing economies and brought to developed economies once the technology has evolved.

- Challenges: the development of a technology on a new trajectory puts new entrants in established markets in competition to reach new technological standards. In emerging economies, the main challenge is the difficulty of reaching a vast market that often lacks adequate complementary assets (such as distribution and logistics infrastructures). Furthermore, cultural and institutional differences make it difficult for foreign firms to understand and properly respond to market needs.

- Competition/success is based on: in traditional disruptive innovation theory, the "battle" is won by the company that develops the new technology better and faster, satisfying at first the request for new attributes and, along within technological evolution, catching up on the mainstream attributes. In reverse innovation, competition is instead based on the ability to develop a new business model that allows companies to serve a large portion of the market in order to achieve large sales volumes and economies of scale. 


\section{Disruptive Innovation in Reverse: Towards a Research Agenda}

In light of the discussion presented in this paper, we can conclude that reverse innovation can be defined as a form of disruptive innovation that originates not from the same geographical market that incumbent companies dominate, but rather from the markets of emerging economies, where a technology/product has been commercialized to fit the characteristics of those markets, particularly serving the vast bottom of the pyramid.

The disruptive innovation framework provides us with the dynamics to look at innovation that originates for emerging economies. However, the challenges, evolution and factors leading to success or failure of reverse innovation are different from those that are relevant when disruptive innovation originates from a developed market.

We therefore argue that instead of simply generalizing the findings of disruptive innovation to emerging economies, future studies should take into consideration innovations that originate for those markets.

Innovating in foreign countries requires a deep understanding of the local culture and business environment. This is particularly true for emerging economies with crucial differences in management and business practices as well as in general social interactions. Guanxi in China represents an exemplar case (Hutchings \& Murray, 2002). We think in-depth studies that focus on low-income growing markets such as China and India are needed for the future.

In particular, contributions should link global innovations deriving from MNC activities in emerging economies and Open Innovation (OI) dynamics. As reported by Seely-Brown \& Hamel (2005), Zeng \& Williamson (2007) and Williamson (2010), organizational structure and business models are key areas to learn how to serve low-income countries and how to develop innovations from those market inputs. In their contributions, several similarities with the OI model can be identified. Innovation is derived from strong local market inputs and therefore developed thanks to (potential) customer cooperation rather than a technological push. Cultural and institutional differences push foreign MNCs to observe and interact with local suppliers and competitors for a reciprocal exchange of information on markets and technologies.

Chesbrough, in his "Open Services Innovation: Rethinking Your Business to Growth and Compete in a New Era" (2011), dedicates a chapter to emerging economies showing how OI can be a fruitful way to reach those markets and learn from them.

Strong intellectual property regimes are required to implement an innovation strategy that is based on an open model. This may be a problem in developing countries since they are shown to have weak intellectual property regimes (IPR) (Zhao, 2006). Despite this, recent contributions show how to overcome this problem in developing economies such as China (Keupp et al, 2009; Quan \& Chesbrough, 2010), presenting successful cases of foreign companies that implement R\&D activities in China, providing useful tools for overcoming the IP violation risk.

As reverse innovation dynamics unfold, we expect to see new business models evolve, new forms of interaction between MNCs and local partners, as well as new opportunities for entrepreneurs trying to adapt technologies across distant markets. 
${ }^{1}$ We are aware that the author's blog is not a strong source but, given the novelty of the topic, the explanation provided in this post is crucial for understanding the concept. The authors further expanded the list of conditions to five (Govindarajan and Trimble, 2012) but they did not comment on the overlapping between reverse and disruptive innovation. 


\section{References}

Acee, H. J. (2001) Disruptive Technologies: an Extended View, SM Thesis, Management of Technology, Massachusetts Institute of Technology, 2001.

Bower, J.L. and Christensen, C.M. (1995) Disruptive technologies: catching the wave. Harvard Business Review. 73, 43-53.

Cefis E. and Marsili O. (2006) Survivor: the role of innovation in firms' survival. Research Policy, 35, 626-641.

Chesbrough, H.W. (2002) Environmental influences upon firm entry into new sub-markets: evidence from the worldwide hard disk drive industry conditionally. Research Policy, 32, 659-678.

Chesbrough, H. (2011) Open Services Innovation. Rethinking your business to growth and compete in a new area, Jossey Bass.

Christensen C.M. and Overdorf M. (2000) Meeting the challenge of disruptive change. Harvard Business Review, 78, 66-76.

Christensen, C. M. (1997) The innovator's dilemma: when new technologies cause great firms to fail, Harvard Business Press.

Christensen, C.M. and Raynor, E. M. (2003) The innovator's solution: creating and sustaining successful growth, Harvard Business Press.

Corso, M. and Pellegrini, L. (2007). Continuous and discontinuous innovation: overcoming the innovator dilemma. Creativity and Innovation Management, 16, 333-347.

Danneels, E. (2004) Disruptive technology reconsidered: a critique and research agenda. The Journal of Product Innovation Management, 21, 246-258.

Di Minin, A. and Bianchi, M. (2011). Safe nests in global nets: internationalization and appropriability of R\&D in wireless telecom. Journal of International Business Studies, 42, 910-934.

Gassmann, O. and Han, Z. (2004) Motivations and barriers of foreign R\&D activities in China. $R \& D$ Management, 34, 423-437.

Govindarajan, V. and Kopalle, P.K. (2006a) Disruptiveness of innovations: measurement and an assessment of reliability and validity. Strategic Management Journal, 27, 189-199.

Govindarajan, V. and Kopalle, P.K. (2006b) The usefulness of measuring disruptiveness of innovations. Ex post in making ex ante predictions. Journal of Product Innovation Management, 23, $12-18$.

Govindarajan V. (2010) The case of 'reverse innovation' now. BusinessWeek Online, 10/27/2009, p. 13.

Govindarajan V. and Trimble C. (2009) Is reverse innovation like disruptive innovation? Harvard Business Review Blog Network: http://blogs.hbr.org/hbr/hbr-now/2009/09/is-reverseinnovation-like-dis.html (accessed on June 14th 2012).

Govindarajan V. and Trimble C. (2012) Reverse innovation: create far from home, win everywhere. Cambridge, MA: Harvard Business Press.

Hang C., Chen J. and Subramian, A.M. (2010) Developing disruptive products for emerging economies: lessons from Asian cases. Research Technology Management, 53, 21-26.

Hart S.L. and Christensen C.M (2002) The great leap. Driving innovation from the base of the pyramid. MIT Sloan Management Review, 44, 51-56. 
Henderson R. (2006) The innovator's dilemma as a problem of organizational competence. Journal of Product Innovation Management, 23, 5-11.

Hutchings K. and Murray G. (2002) Working with guanxi: an assessment of the implications of globalisation on business networking in China. Creativity and Innovation Management, 11, 184191.

Immelt J.R., Govindarajan V. and Trimble C. (2009). How GE is disrupting itself. Harvard Business Review, 87, 56-65.

Utterback J.M. (2004) The Dynamics of Innovation. Educause Review, January-February, 42-51.

Kenney M., Massini S. and Murtha T.P. (2009) Offshoring administrative and technical work: new fields for understanding the global enterprise. Journal of International Business Studies, 40, 887-900.

Keupp M.M., Beckenbauer A. and Gassmann O. (2009) How managers protect intellectual property rights in China using de facto strategies. $R \& D$ Management, 39, 211-223.

London T. and Hart S.L. (2004) Reinventing strategies for emerging markets: beyond the transnational model. Journal of International Business Studies, 35, 350-370.

Markides C. (2006) Disruptive innovation: in need of better theory. Journal of Product Innovation Management, 23, 19-25.

Patel P. and Pavitt K. (1991) Large firms in the production of the worlds technology - An important case of non-globalization. Journal of International Business Studies, 22, 1-21.

Prahalad C.K. and Hart S.L. (2002) The fortune at the bottom of the pyramid. Strategy + Business, 26, 54-67.

Prahalad C. K. (2004) The fortune at the bottom of the pyramid. Eradicating poverty through profits, Pearson Education.

Quan X. and Chesbrough H.W. (2010) Hierarchical segmentation of R\&D process and intellectual property protection: evidence from multinational $\mathrm{R} \& \mathrm{D}$ laboratories in China. IEEE Transactions on Engineering Management, 57, 9-21.

Sandström C., Magnusson M. and Jörnmark J. (2009) Exploring factors influencing incumbents' response to disruptive innovation. Creativity and Innovation Management, 18, 8-15.

Seely Brown J. and Hagel J. III (2005) Innovation blowback: disruptive management practices from Asia. The Mckinsey Quarterly, 1, 34-45.

Suzuki J. and Kodama F. (2004) Technological diversity of persistent innovators in Japan: two case studies of large Japanese firms. Research Policy, 33, 531-549.

Utterback J.M. and Acee H.J. (2005) Disruptive technologies: an expanded view. International Journal of Innovation Management, 9, 1-17.

Vernon R. (1966) International Investment and International Trade in the Product Cycle. Quarterly Journal of Economics, 80, 190-207.

Von Zedwitz M. (2004) Managing foreign R\&D laboratories in China. R\&D Management, 34, 439-452.

Walsh S.T., Kirchhoff B.A. and Newbert S. (2002) Differentiating market strategies for disruptive technologies. IEEE Transaction on Engineering Management, 49, 341-351.

Williamson P.J. (2010) Cost innovation: preparing for a 'value-for-money' revolution. Long Range Planning, 43, 343-353.

Williamson P.J. and Zeng M. (2004) Strategies for competing in a changed China. MIT Sloan Management Review, 45, 85-91. 
1

2

3

4

5

6

7

8

9

10

11

12

13

14

15

16

17

18

19

20

21

22

23

24

25

26

27

28

29

30

31

32

33

34

35

36

37

38

39

40

41

42

43

44

45

46

47

48

49

50

51

52

53

54

55

56

57

58

59

60

Zeng M. and Williamson P.J. (2007) Dragons at your door: how Chinese cost innovation is disrupting the rules of global competition. Boston, MA: Harvard Business School Press.

Zhao M. (2006) Conducting R\&D in countries with weak intellectual property rights protection. Management Science, 52, 1185-1199. 